\title{
The Public Participation Shifting of Environmental Impact Assessment During Covid-19 Outbreak
}

\author{
Adib Hasan, 1*, Erri N. Megantara ${ }^{2}$ \\ ${ }^{1}$ Environmental and Energy Management, Twente University, the Netherlands \\ ${ }^{2}$ Environment Science Program, Postgraduate School, Universitas Padjadjaran, Indonesia
}

\begin{abstract}
Environmental Impact Assessment (EIA) is not only about development and protecting environment, but also about public participation during all the process. It is not an exaggeration that public participation is claimed as one of the key indicators of the effectiveness of EIA. Therefore, even in pandemic conditions while development still must go on at the same time, public participation can be avoided in the EIA process. In a wide range of international arrangements and national regulation, there are several guidance in accommodating public participation such as the Aarhus Convention 1998 and Indonesian national regulation. This article compares and analyses those legal procedures in mitigating unexpected conditions. The result shows that both of them are still feasible to be applied even in abnormal circumstances. Some barriers are identified especially related to implementing advanced technology. Therefore, how these aspirations are conveyed and accepted must be done in various alternative ways.
\end{abstract}

\section{Introducion}

The importance of public participation in the environmental decision-making process has been acknowledged by several international conferences, namely the United Nations (UN) Rio Conference 1992 and Aarhus Convention in 1998. In the UN 1992 Rio Conference on Environment and Development, specifically in principle 10 stated that "environmental issues are best handled with the participation of all concerned citizens at the relevant level" [1]. Then, in Aarhus Convention 1998, a convention on Access to Information, Public Participation in Decision Making and Access to Justice in Environmental Matters, examinated minimum requirements for public participation in various environmental decision-making categories. This convention briefly stated to "guarantee the rights of access to information, public participation in decision-making, and access to justice in environmental matters in accordance with the provisions of this Convention" (Aarhus Convention 1998). These public participation benefits have to be maintained even in unnormal conditions.

Once declared as a global pandemic, the Corona Virus 2019 (Covid-19) has encouraged governments around the world to shift the way people interact with each other. In Facing this problem, several sectors like education and work sector have to transform their behaviour. Regular face-to-face activities such as the teaching-learning process in class and office meetings should be limited due to physical restriction activities imposed by the state authority. One successful key element in applying this shifting is the use of information, communication, and technology (ICT) [3]. Long before the Covid-19 outbreak, Persada et al. (2015) claimed that altering the way the public delivers their opinion from a regular base to ICT base has a chance in saving time and money [4].
This article intends to explore 'what are possible options to overcome the pandemic condition'? Actions of these, then, evaluate by using the General Principle of the Aarhus Convention to give an answer to the second question 'to what extent is the Aarhus Convention being accommodated by the chosen country regulation?.

\section{Methodology}

The first thing that we did was conducting a literature review on the use of public participation within EIA by using ScienceDirect's search tool. We searched research articles and book chapters using the search filed for each keyword relevant for the scope of the research ("environmental impact assessment"," EIA", "public participation". After that, we combined it with the keywords of "covid-19" and/or "Aarhus Convention". On first page of this result, we chose two articles that the most suitable and the most recent. In order to find more relevant papers, the snowball method was also applied and additional keywords were used. For additional information, especially which came from Indonesia, we used GoogleScholar especially for articles with 'Bahasa' by using the translation keyword.

There is no research article that discussed EIA responses to covid-19 yet, therefore authors initiated to find research papers that have innovation in conducting public participation. As the result, three articles have been chosen which are using social media [5], visual tools [6], and using information technology [7]. These tools are assumed able to tackle public participation problems related to covid-19. To evaluate public participation of EIA principle in Indonesia law and regulation, Authors have chosen an international legal instrument, the Aarhus Convention, that mostly used by developed countries in Europe. 
*Note: At the time of completion of this paper, the Law that became the reference for AMDAL, Law $32 / 2009$ underwent amendments with the issuance of Law 11 of 2020 . However, this paper still uses the old Law as a reference.

\section{Result}

\subsection{Definition of Public Participation}

The simple term "the public" actually refers to a complex amalgam of interest groups, which changes over time and from project to project [8]. According to Bishop [9] public is diffused, but at the same time highly segmented into interest groups and geographic communities and individuals. There are sets of groups of "publics" that have common goals, ideals, and values. There are many different groups and individuals that make up the public. For any decision, 'the public' consists of those people who see themselves as significantly affected (Praxis as cited in Brenneis [10]).

Standards of Public Participation, 2008, defines public participation as the change of all those concerned and/or interested to present and/or stand up for their interests or concerns in the development of plans, programmes, policies, or legal instrument. Other definition also can be found in several scientific papers such as definition that arranged by Graham Smith in Rowe \& Frewer [11] whose stated that public participation in such a way that 'it encompasses a group of procedures designed to consult, involve, and inform the public to allow those affected by a decision to have an input into that decision'. A simple definition also came from Beierle \& Cayford, (2002) but by underlying the extended composition of participation to 'the lay public or their representative'. These definitions underline the mechanism of participation and focus on 'organized bureaucratic processes'. It means other mechanisms such as political power, lawsuits, or extralegal protests are excluded.

On the other hand, the Environmental Protection Agency of the US defines public participation as part of the decision-making process through which responsible officials become aware of public attitudes by providing ample opportunity for interested and affected parties to communicate their views (EPA-US, 1979). For European, the public participation is closely related to deliberative process. The European Institute for Public Participation (EIPP) defines public participation as "a deliberative process by which interested or affected citizens, civil society organizations, and government actors are involved in policy-making before a political decision is taken" (EIPP, 2009).

According to the National Research Council of the National Academies of the USA (NRC), there are six different concepts of public participation, namely the functionalist approach; the neo-liberal theory; the deliberative approach; the anthropological concept; the emancipatory view; and the postmodern perspective [15]. Each of them has its own philosophical backgrounds and objectives. Therefore, they also have different rationales, tasks, and instruments.
Table 1 The Six Concept of Public Participation

\begin{tabular}{|c|c|c|c|}
\hline Concept & Main Objective & Rationale & $\begin{array}{l}\text { Models and } \\
\text { Instruments }\end{array}$ \\
\hline Functionalist & $\begin{array}{l}\text { To improve quality of } \\
\text { decision output }\end{array}$ & $\begin{array}{l}\text { Representation of all } \\
\text { knowledge holders; } \\
\text { systematic integration } \\
\text { of } \\
\text { experiential and local } \\
\text { knowledge }\end{array}$ & $\begin{array}{l}\text { Workshops, hearings, } \\
\text { inquiries, citizen } \\
\text { advisory } \\
\text { committees }\end{array}$ \\
\hline Neo-liberal & $\begin{array}{l}\text { To identify and } \\
\text { balance all values and } \\
\text { preferences in } \\
\text { proportion to their } \\
\text { presence in the } \\
\text { affected population }\end{array}$ & $\begin{array}{l}\text { Informed consent of } \\
\text { the } \\
\text { affected population; } \\
\text { reach win-win or } \\
\text { compensatory } \\
\text { solutions, or at least } \\
\text { compromise, through } \\
\text { discussion }\end{array}$ & $\begin{array}{l}\text { Referenda, focus } \\
\text { groups, } \\
\text { internet-participation, } \\
\text { negotiated rule- } \\
\text { making, } \\
\text { mediation etc. }\end{array}$ \\
\hline Deliberative & $\begin{array}{l}\text { To realise the } \\
\text { common } \\
\text { good in the final } \\
\text { decision }\end{array}$ & $\begin{array}{l}\text { Inclusion of relevant } \\
\text { arguments, reaching } \\
\text { consensus through } \\
\text { communication }\end{array}$ & $\begin{array}{l}\text { Discourse-oriented } \\
\text { models, ritizen } \\
\text { forums, deliberative } \\
\text { juries }\end{array}$ \\
\hline Anthropological & $\begin{array}{l}\text { Common sense as } \\
\text { ultimate arbiter in } \\
\text { making decision }\end{array}$ & $\begin{array}{l}\text { Inclusion of non- } \\
\text { interested laypersons } \\
\text { representing basic } \\
\text { social categories such } \\
\text { as gender, income and } \\
\text { locality }\end{array}$ & $\begin{array}{l}\text { Consensus, } \\
\text { conference, } \\
\text { citizen juries, planning } \\
\text { cells }\end{array}$ \\
\hline Emancipatory & $\begin{array}{l}\text { To empower less } \\
\text { privileged groups and } \\
\text { individuals, and to } \\
\text { ultimately change the } \\
\text { power structure }\end{array}$ & $\begin{array}{l}\text { Strengthening the } \\
\text { resources of those } \\
\text { who } \\
\text { suffer most from } \\
\text { environmental } \\
\text { degradation }\end{array}$ & $\begin{array}{ll}\begin{array}{l}\text { Action } \\
\text { initiatives, } \\
\text { town } \\
\text { community } \\
\text { development }\end{array} & \\
\text { tribunals, groups, } & \text { science } \\
\text { workshops } & \end{array}$ \\
\hline Post-modern & $\begin{array}{l}\text { To demonstrate } \\
\text { variability, plurality } \\
\text { and legitimacy of } \\
\text { dissent }\end{array}$ & $\begin{array}{l}\text { Acknowledgment of } \\
\text { plural rationalities; no } \\
\text { absolute decision } \\
\text { necessary; mutually } \\
\text { acceptable } \\
\begin{array}{l}\text { arrangements are } \\
\text { sufficient }\end{array}\end{array}$ & $\begin{array}{ll}\text { Open forums, } & \text { open } \\
\text { space } & \\
\text { conferences, } & \text { panel } \\
\text { discussions } & \end{array}$ \\
\hline
\end{tabular}

Source: Public Participation in Environmental Assessment and Decision Making published by the $\mathrm{NRC}$ in 2008, pp. 48-49

To achieve the quality of decision and to meet the complex needs of society, functionalist perspective emphasizes the comprehensive collection of knowledge and values. It has the potential to gain legitimacy in decision-making. Slightly different from the functionalist, neo-liberal theory focuses on identifying individual interests and appeals, which try to find a winwin or compensatory solution. Thus, the balance between individual interests and values can be achieved. Next, the deliberative approach underlines the communication process among rational actors based on knowledge or potential consequences and agreement on basic human values and moral standards. Then, the anthropological/pragmatist concept uses the third parties, an independent jury, that have the capability to employ their common sense when making a decision in the presence of conflicting interests. The jury make the decision based on their own pre-existing preferences and circumstances. On the contrary, the emancipatory perspective reaches its goals through the participation of the 'powerless' citizen. Lastly, the post-modern emphasizes the power relations and the diversity of factual claims, opinions, and values. It uses a formal 
participatory procedure which appears more like mediation. By this formal participatory, it is expected to employ broad knowledge, raise public demands, reach an incremental decision, and ultimately enhance the legitimacy of the decision [16][15].

\subsection{The Important of Public Participation in EIA}

Morgan (1998, p. 147) claims that: "Public participation is critical to the success of EIA" [17][18]. Even though EIA has been accepted by hundreds of countries around the world, the type of public participation can be different. For example, EIA in Canadian's Northwest Territories requires an arrangement between the local community as the land claimer and prospectus projects. In Canadian's Northwest Territories, Aboriginal Communities as the local community have a right to decide their land fate including nominating their representative in Environmental Board Member in majority number [19].

O'Faircheallaigh, (2010) conclude that there are three broad purposes of public participation in EIA, which are: obtain public input into decision taken elsewhere; share decision making with the public; and alter distribution of power and structures of decision making. Each of them has their own specific purposes. For instance, the specific purposes of the early one is to provide information to the public, fill information gaps, information contestability, and problem-solving and social learning. Then, the second one has specific purposes which reflect democratic principle, democracy in practice, and pluralist representative. For the last one, the specific purposes are to involve marginalised groups, shifting the locus of decision making, and entrench marginalisation.

Regards to the methods of public participation, Coenen (2009) suggested it depends on their own purposes. He divided it into three basic purposes as shown in table 2 .

Table 2: Purposes and Appropriate Methods of Public Participation

\begin{tabular}{|l|l|}
\hline Purpose & Appropriate methods \\
\hline $\begin{array}{l}\text { Additional source of ideas } \\
\text { and information }\end{array}$ & $\begin{array}{l}\text { Citizens' jury } \\
\text { Consensus conferencing } \\
\text { Focus groups } \\
\text { Deliberative opinion poll } \\
\text { Citizens' panel } \\
\text { Referendum } \\
\text { Teledemocracy }\end{array}$ \\
\hline $\begin{array}{l}\text { Monitoring and appraisal } \\
\text { by citizen }\end{array}$ & $\begin{array}{l}\text { Community needs analysis } \\
\text { Priority search } \\
\text { Public scrutiny } \\
\text { Village appraisal } \\
\text { Parish mapping }\end{array}$ \\
\hline
\end{tabular}

\begin{tabular}{|l|l|}
\hline Purpose & Appropriate methods \\
\hline & Community indicators \\
\hline $\begin{array}{l}\text { Broadening of public } \\
\text { support and reducing the } \\
\text { level of conflict by } \\
\text { bringing stakeholders } \\
\text { (including government) } \\
\text { together }\end{array}$ & $\begin{array}{l}\text { Public meetings } \\
\text { Planning for real mediation } \\
\text { Consensus-building } \\
\text { Future search } \\
\text { Community visioning } \\
\text { Round table }\end{array}$ \\
\hline
\end{tabular}

\subsection{Covid-19 Effects}

The outbreak of Covid-19 has affected human life, the economy, and the environment. The social restriction has made economic growth decreased and even minus. To minimize these negative effects, several countries have loosened their environmental policy, like the United States, through an executive order by the President that waives requirements under a suite of environmental law. The new order accelerates the permit of construction projects and energy projects using emergency authorities to skirt environmental regulations with little public notice [22]. Australia has the same notion. The recent Queensland omnibus legislative changes have given the Minister the power to make a declaration waiving the requirement to comply with certain conditions of an environmental approval [23].

\subsection{Public Participation in Aarhus Convention}

Aarhus Convention is an international law that claimed as the most advanced legal documents which recognised and promoted public participation in environmental protection [16]. To be understood, recognizing public participation in the decision-making process is accommodated by several international laws. However, some of them are not clearly mentioned decisionmaking process in the environmental realms such as the Universal Declaration of Human Rights (1948), International Covenant on Civil and Political Rights (1966), and the Treaty of Lisbon (2009). The Universal Declaration of Human Rights stated that 'everyone has the right to take part in the government of his country, directly or through freely chosen representatives'. Next, In Article 25a of ICCPR stated that 'every citizen shall have the right and opportunity, without any of the distinctions mentioned in Article 2 and without unreasonable restrictions: to take part in the conduct of public affairs, directly or through freely chosen representatives'. Then, in the Treaty of Lisbon, Article 10 (3) 'Every citizen shall have the right to participate in the democratic life of the Union. The decision shall be taken as openly and as closely as possible to the citizen'.

Even though the international laws are in the environmental realm, but those are not detail enough, for instance, the United Nations Framework Convention on Climate Change (1992) and the Kyoto Protocol (1998). 
In UNFCCC, the public participation still in Article 6 (a) stated that the parties shall promote and facilitate at the national and, as appropriate, sub regional and regional levels, and in accordance with national laws and regulations, and within their respective capacities: (iii) public participation in addressing climate change and its effects and developing adequate responses'. Then in the Kyoto Protocol, Article 12 (9) stated that 'participation under the clean development mechanism, including in activities mentioned in paragraph 3(a) above and in the acquisition of certified emission reductions, may involve private and/or public entities, and is to be subject to whatever guidance may be provided by the executive board of the clean development mechanism'.

In connecting between the Aarhus Convention and Covid-19, UNECE, 2002 claimed the Aarhus Convention provides for a number of obligations. For instances, the provision of effective public access to information related to COVID-19 matters, such as the origin of the virus; related impacts on biodiversity and ecosystems, on other objects of the environment and on human health; and how to ensure effective procedures of public participation in decision-making on legislation, plans, policies, and projects related to these matters. Furthermore, since the Aarhus Convention supports governance and accountability, it is important to maintain and strengthen this treaty. The Aarhus Convention contributes to more effective decisionmaking, innovative solutions, and facilitates the capturing of key local knowledge in environmental matters. Moreover, this treaty also builds public consensus and foster a sense of trust in the authorities [24].

In general, there are three main public right that stipulated in the Aarhus Convention, which are, access to information, public participation, and access to justice. The rules about public participation are in articles 6, 7, and 8. From those articles, Hartley \& Wood (2005) saw that there were six key public participation requirements of the Aarhus Convention emphasise the need to: time participation programmes to achieve 'early' participation; provide the public with access to all documentation relevant to the decision-making process; enter into discussions with the public concerned; allow the public to submit their opinions at public inquiries; consider the outcome of public participation in the decision-making process; and achieve 'effective' participation[25]. Each of these key principles can be acted as evaluation criteria the implementation of environmental law and its implementation.

In responding to the covid-19, the European Countries that acknowledge the Aarhus Convention, like the UK and the Netherlands, intent to use social media to inform and gather public aspiration related to respond the planning application extensively. In the UK, before the pandemic, they still used newspapers and physical meetings to inform the public and gather their responses. But, after the covid-19, the ministry of Housing, Communities, \& Local Government has made changes in their 'guidance of consultation and predecision matters' as of 13 May 2020. The UK considers to use social media and other electronics media instead of the local newspaper to inform the publics due to the planning application [26]. On the other hand, in the Netherlands, there is no meaningful change because all of their EIA steps are digital basis and formal public participation is not required by law.

\subsection{Public Participation in Indonesian Regulation}

Even though Indonesia formally introduce Environmental Impact Assessment (in Indonesia language referred as Analisis Mengenai Dampak Lingkungan/AMDAL) in 1982, the provision about the need for public involvement in EIA was just acknowledging in 2000 by issues Government Regulation No. 27/1999. Before that, the public involvement consisted as part of EIA, but not in a specific regulation [17].

In 2009, the Indonesian government renewed a regulation related to Environmental Protection and Management by issued the Law number 32/2009. This law, in general, governs how to protect and manage the environment and in terms of EIA include in it. Detail how the EIA works and modules how to govern public participation are regulated in Indonesia Government Regulation number 27/2012 and Ministry of Environment regulation number 17/2012 in respectively.

In these regulations, public participation should be done in two ways. The first one is while preparing the EIA document through the process of announcement, public advice, opinion, and response, consultation and including the public as part of EIA Commission Assessor. The other one is when the announcement of environment licensing application and then when the environment licensing is granted. Details of it can be seen in diagram 1, as below:

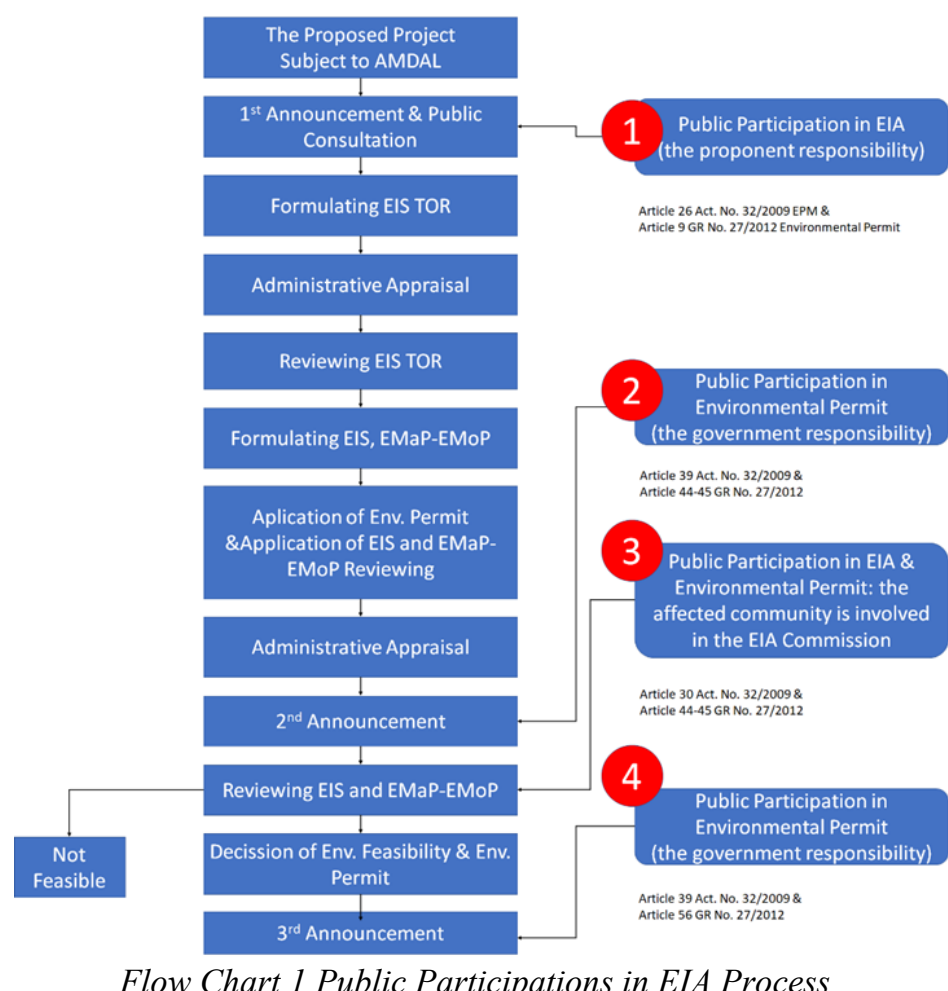

Flow Chart 1 Public Participations in EIA Process 
Those regulations also mentioned the base principle of public participation, which are providing transparent and complete information; equality of position among the parties involved; solving problems that are fair and wise; and coordination, communication, and cooperation among the concerned parties. Through this process, the government aims that the public can get information about plan of businesses and/or activities that have a significant impact on the environment. So, the public can submit their suggestion, opinions, and responses to the plans as a form of public involvement in the decision-making process.

There are three types of public in these regulations, which are affected community, environmentalism, and people who are affected by all forms of decisions on the EIA process. The information has to deliver to them by abiding the standard of detailed information, media, and duration. Detail of information has involved: name and address of initiator; type of business and/or activity plan; scale; potential impacts that will arise; the date the announcement was posted and the deadline for giving suggestion, opinion, and response; and the last, the name and address of initiator and environmental agencies who will receive the suggestion, opinions, and responses.

For the media, the government differentiates it into two kinds of media: the mandatory which are newspaper (local and/or national) and announcement board that easy to access. Then, the supplementary which are another kind of media such as leaflet, poster, and banner; electronic (TV, radio, website, social media, and text message); and announcement board where environmental agencies. All of the announcement is made within a period of ten working days.

Despite all kind of types of announcements, the initiator of the project also has to gain public participation by public consultation. This method is claimed more effective and efficient in receiving public aspiration since it gathers the public in one time and one place.

In responding the Covid-19, Indonesia government enacted two Circular Letter through the Ministry of Environment and Forestry, which are number SE.7/PKTL/PDLUK/PLA/4/4/2020 about the implementation of environmental document assessment in an emergency response effort to prevent the spread of Covid-19 and number P.5/ PKTL/PDLUK/OTL.0/5/2020 about the online mechanism for assessing EIA documents in the context of Preventing the Spread of Covid-19.

\section{Discussion}

Aarhus Convention has been emphasized the importance of public participation in the environmental decision-making process by accommodated three kinds of human rights: Access to Information, Public Participation, and access to justice in environmental matters. Nowadays, the convention principles have been accommodated by national law of many countries especially in Europe. Even though Indonesia is not a part of the EU, Authors assumed that how the Convention and the states implemented that principle can be a good lesson learn for Indonesia in implementing Environmental Impact Assessment.

To make the Aarhus Convention applicable, the Convention has to translate into European Union Law in Directive 2003/35/EC which makes a series of modifications and regulatory changes to the EIA and the integrated pollution prevention and control system to ensure that the procedures are appropriately aligned with the requirements of the Aarhus Convention. Meanwhile, in Indonesia, details of public participation are ruled in several levels of regulations: Act, Government Regulation, and Ministry Regulation.

Reflecting the definition of public participation that came from experts or organizations, it can be concluded that the main point of the public is in the process. EIA lies at the crossroad where economic, environmental, and social values intersect. Balancing these values requires a holistic approach, a collaborative effort between governments, business sectors, and the public. In order to achieve lasting environmental protection and sustainable economic growth and development, public participation must figure prominent in the EIA process [27]. Thus, whatever the way is, public participation principles are the main target.

Fig. 1. Caption of the Figure 1. Below the figure.

\subsection{The Use Technology}

Traditional methods in gaining public participation are common and relatively cheap. However, it can be altered by the revolution of technology in communication[21]. In this perspective, can be seen, of course, the outbreak of the covid-19 acts as a booster to accelerate in improving methods. The use of technology to gain public participation has been acknowledged since last decades by several researchers such as Hanzl, (2007); Pflughoeft \& Schneider (2020); Roque de Oliveira \& Partidário ( 2020).

In the use of technology, Hanzl (2007) was used it to gain public participation in urban planning. Several technologies that he used are three dimensions (3D) models network presentation, Virtual Reality Modelling Language (VRML) which can be accessed from internet browser, Geographic Information Systems (GIS), and games. The chosen technology can be adjusted base on the purposes of public participation. Through these technologies, there are goals that can be achieved: provide a communication platform suppressing a barrier of non-professionalism; allow for distant contacts; and manage a participatory planning process.

Pflughoeft \& Schneider (2020) saw a big potential of using social media in gaining public participation in various sectors. Social media that emphasis in this study are the informal platform, like Facebook, Twitter, and Blooger. Respondents of this paper kind if governmental bodies involve in social media discussion and put their aspiration into actual actions.

An interesting tool has been develop by Pflughoeft \& Schneider (2020); Roque de Oliveira \& Partidário ( $2020)$ to promote inclusive public participation. The idea was by creating visual tools to create a better perception of alternatives, and the understanding of 
complex phenomena. The paper concluded that the effectiveness of the visual tools depends on the nature and design of each visual tools, cultural, social, or political context.

The experience of implementing technology in the paper above shall be a good lesson for implementing more advanced technology in the EIA process in a pandemic condition like covid-19. More importantly in the use of information, communication, and technology as tools to facilitate working activities in pandemic condition as suggested by Dwivedi et al., (2020; Persada et al., (2015). The use of facebook, twitter, and other social media is an example of one-way communication, and for two-ways interactive consultation may used Zoom, skype, or Microsoft Team.

\subsection{Aarhus Convention Principle and Indonesian Law and Regulation}

Aarhus Convention already given their guidance related to public participation as stated in Article 6 of the Convention. If these principles compare to the Indonesian law and regulation, it can be seen as the table 3 below:

Table 3 Comparation between Arhus Convention Principles and Indonesian Law and Regulations

\begin{tabular}{|c|c|}
\hline $\begin{array}{l}\text { Arhus Convention } \\
\text { Principles (Article 6) }\end{array}$ & $\begin{array}{l}\text { Indonesian Law and } \\
\text { Regulations* }\end{array}$ \\
\hline $\begin{array}{l}\text { The public concerned } \\
\text { shall be informed, either } \\
\text { by public notice or } \\
\text { individually as } \\
\text { appropriate, early in an } \\
\text { environmental decision- } \\
\text { making procedure, and } \\
\text { in an adequate, timely } \\
\text { and effective manner. }\end{array}$ & $\begin{array}{l}\text { Public received four } \\
\text { opportunities in } \\
\text { delivering their opinions } \\
\text { related to the project. }\end{array}$ \\
\hline $\begin{array}{l}\text { The public participation } \\
\text { procedures shall include } \\
\text { reasonable time-frames } \\
\text { for the different phases, } \\
\text { allowing sufficient time } \\
\text { for informing the public }\end{array}$ & $\begin{array}{l}\text { The time frame is } \\
\text { different among the four } \\
\text { opportunities }\end{array}$ \\
\hline $\begin{array}{l}\text { An indication of the } \\
\text { public authority from } \\
\text { which relevant } \\
\text { information can be } \\
\text { obtained and where the } \\
\text { relevant information has } \\
\text { been deposited for } \\
\text { examination by the } \\
\text { public }\end{array}$ & $\begin{array}{l}\text { Newspaper, billboard of } \\
\text { government, and/or } \\
\text { multimedia platforms. }\end{array}$ \\
\hline $\begin{array}{l}\text { Each party shall require } \\
\text { the competent public } \\
\text { authorities to give the } \\
\text { public concerned access } \\
\text { for examination, upon } \\
\text { request where so } \\
\text { required under national } \\
\text { law, free of charge and }\end{array}$ & $\begin{array}{l}\text { Ruled in different } \\
\text { regulation. The Law } \\
\text { Number } \\
\text { regarding Openness of } \\
\text { Public Information }\end{array}$ \\
\hline
\end{tabular}

as soon it becomes

available, to all

information relevant to

the decision-making

Each party should, Public Consultations

where appropriate, have to conduct by the

encourage prospective Proponent; Public

applicants to identify the Representative being a

public concerned, to part of EIA commission.

enter into discussions,

and to provide

information regarding

the objectives of their

application before

applying for a permit

Procedures for public

participation shall allow

the public to submit, in

writing or, as

appropriate, at a public

hearing or inquiry with

the applicant, any

comments, information, analyses or opinions that it considers relevant to the proposed activity.

Each party shall ensure Public opinions are that in the decision due guaranteed to hear, but account is taken of the not sure being a part of outcome of the public the final decision.

participation.

Each party shall provide Public Consultations in for early public the planning phase of the participation, when all project should be options are open and conducted by the effective public proponent.

participation can take place.

* Indonesia Law Number 32/2009 Government Regulation Number 27/2012 Ministry of Environmental Number $17 / 2012$

From the table, we concluded that almost all of the Aarhus principles are accommodated by Indonesian regulation but in different approaches. In terms of timeframe, Indonesian regulation provides four times to deliver their aspirations. However, how this aspiration being accommodated or not, the public does not have certainty about that. Then in the aspect of access to information, instead of mentioning it in the law of environmental protection and management, it is mentioned in the law of Openness of Public Information number $14 / 2008$. This regulation, in general, related to access to all information on public services.

Putting access to information on different regulations has both positive and negative sides. For the positive side, the right of the public has been acknowledged. Moreover, in that regulation, the public also has a right to sue the public officer if they not provide sufficient information. However, sometimes the public may not realize that they have a certain right in the environmental matter since it is not in the environmental law regime. 


\subsection{Challanges}

An online seminar was held by the Environment Research Centre of Sebelas Maret University on 5 June 2020 about EIA Preparation and Document Assessment in the New Normal Era. For the speakers, this seminar invited government bodies at the ministry and provincial level. Several problems were identified and discussed. Then, in the end, possible solutions were offered. The main problems of it are access to location and access to internet connection..

\subsubsection{Access to Location}

Instead of lockdown, the Indonesian Government used a high scale of social restriction terminology. Province, city, and district are given colour marks depend on Covid-19 suspected level. The red colour is for an area with high number suspected, yellow for low level of suspected, and green for a safe area or no suspect. The type of colour is decided by local government after got insight from a task force to accelerate the handling of covid-19.

In EIA process, a project proponent has to gather information and sample from a location that the project would be. The gathering information process could be a kind of public participation that use to know public respond to the project. Then, the sample will be delivered to laboratory to be checked its chemical and biological compounds. However, the high scale of social restriction has a potential to disturb this process. Hence, in certain area, strangers are not allowed to enter the area.

\subsubsection{Access to internet connection}

Even though Indonesia rank $6^{\text {th }}$ for internet user in the world in 2019, for the portion it just no more than 50 of the population (Statistics Indonesia, 2020) [29]. Therefore, it is no wonder if in certain places, inhabitants do not have access to the internet, especially for those living in rural areas. Even, if internet access is already available, a stable connection also becomes a problem.

The Ministry of Environment and Forestry released that several steps of EIA process are affected such as public consultation, gathering data, reviewing term of reference (TOR) of EIA, and reviewing Environmental Impact Statement \& Environment Management Planning - Environment Monitoring Planning. To overcome these problems, the Ministry of Environment and Forestry issued Ministry Regulation about Online Assessment Mechanism of EIA document due to spreading prevention of Covid-19. The mechanisms that need to be taken into account are optimal in using video conference but still obeying all legal procedures. In applying this new procedure, the province of Central Java has held five times reviewing EIA documents by using video conference.

\section{Conclusion}

Although public participation is widely documented in the literature as being a valuable component of the EIA process, it is apparent that the degree to which each of the practice evaluation criteria is fulfilled depends upon the public participation methods used and the way they have been implemented, as well as upon the personal beliefs of the stakeholders [25]. Therefore, even in a hard condition like pandemic covid-19, public services related to environment protection and management should not be ignored. One of them is public participation in the process of environmental impact assessment.

Public participation in the decision-making of environmental matters is one of the public rights that has been acknowledged by international particularly through the Aarhus Convention that Authors used to assess Indonesian regulations. Through this study, Authors found that public participation in the Environmental Impact. In there, if necessary, they may informal media such as facebook, twitter, or blogger to inform and gather public opinions regard to the environmental application. Almost similar approach being happen in Indonesia. The use of online meeting assessment is already accommodated, but not in using social media yet. However, to make all public participation on an online basis there are some barriers, such as the electronic devices and a good internet connection especially for those who live in rural areas.

Second, in practice, countries that ratified the Aarhus Convention have flexibility in gathering public opinion. It can be seen in the European Countries EIA website in which there some adjustments in that process like the UK did. In there, if necessary, they may informal media such as facebook, twitter, or blogger to inform and gather public opinions regard to environmental application. Almost similar approach being happen in Indonesia. The use of online meeting assessment is already accommodated, but not in using social media yet. However, to make all public participation on an online basis there are some barriers, such as the electronic devices and a good internet connection especially for them who live in rural areas.

\section{Acknowledgment}

We gratefully acknowledge the financial support provided by the Ministry of National Development Planning/ National Development Planning Agency.

\section{References}

1. UN, Rio Declaration on Environment and Development. Rio de Janeiro: United Nations, (1992).

2. United Nations Economic Commission for Europe, Convention on Access to Information, Public Participation in Decision-Making And Access to Justice in Environmental Matters. Geneva: UNECE, (1998). 
3. Y. K. Dwivedi et al., "Impact of COVID-19 pandemic on information management research and practice: Transforming education, work and life," Int. J. Inf. Manage., no. July, p. 102211, 2020, doi: 10.1016/j.ijinfomgt.2020.102211.

4. S. F. Persada, S. Lin, R. Nadlifatin, and M. Razif, "A lean based analysis on the Indonesian citizens ' participation in environmental impact assessment (EIA): a potential improvement through web based system and SMS-gateway," Open Access J. Inf. Syst., pp. 1-6, 2015, [Online]. Available: http://is.its.ac.id/pubs/oajis/index.php.

5. B. R. Pflughoeft and I. E. Schneider, "Social media as E-participation: Can a multiple hierarchy stratification perspective predict public interest?," Gov. Inf. Q., vol. 37, no. 1, 2020, doi: 10.1016/j.giq.2019.101422.

6. A. Roque de Oliveira and M. Partidário, "You see what I mean? - A review of visual tools for inclusive public participation in EIA decision-making processes," Environ. Impact Assess. Rev., vol. 83, no. May, p. 106413, 2020, doi: 10.1016/j.eiar.2020.106413.

7. M. Hanzl, “Information technology as a tool for public participation in urban planning: $a$ review of experiments and potentials," Des. Stud., vol. 28, no. 3, pp. 289-307, (2007), doi: 10.1016/j.destud.2007.02.003.

8. J. Glasson, R. Therivel, and A. Chadwick, Introduction to Environmental Impact Assessment. Taylor \& Francis, (2013).

9. A. Bishop Bruce, "Communication in The Planning Process," in Public Involvement Techniques, J. L. Creighton, J. D. Priscoli, and C. M. Dunning, Eds. Alexandria, VA: Institute for Water Resources, (1998), pp. 85104.

10. K. Brenneis, "An evaluation of public participation in the British Columbia Ministry of Forests," (1990).

11. G. Rowe and L. J. Frewer, "Public participation methods: A framework for evaluation," Sci. Technol. Hum. Values, vol. 25, no. 1, pp. 3-29, (2000), doi: $10.1177 / 016224390002500101$

12. T. Beierle and J. Cayford, Democracy in Practice: Public Participation in Environmental Decisions. Washington, DC: Resources for the Future, (2002).

13. EPA(US), Public Participation in Programs under the Resource Conservation and Recovery Act, the Safe Drinking Water Act, and the Clean Water Act. EPA (US), (1979).

14. European Institute for Public Participation (EIPP), "Public Participation in Europe An international perspective," no. June, pp. 1-49, (2009), [Online]. Available:

http://www.qualitapa.gov.it/nc/risorse/pubblic
azioni/?eID=dam_frontend_push \&docID $=187$ 3.

15. N. R. Council, Public Participation in Environmental Assessment and Decision Making. Washington, DC: The National Academies Press, (2008).

16. H. Lang, "Public participation in environmental decision-making in China: Toward an Ecosystem approach," University of Groningen, (2014).

17. D. Purnama, "Reform of the EIA process in Indonesia: Improving the role of public involvement," Environ. Impact Assess. Rev., vol. 23, no. 4, pp. 415-439, (2003), doi: 10.1016/S0195-9255(03)00046-5.

18. R. K. Morgan, Environmental impact assessment: a methodological perspective. Dordrecht: Kluwer Academic Publishers, (1998).

19. M. W. Boyco, "Public Participation: EIA in Northern Canada and South Africa," (2010).

20. C. O'Faircheallaigh, "Public participation and environmental impact assessment: Purposes, implications, and lessons for public policy making," Environ. Impact Assess. Rev., vol. 30, no. 1, pp. 19-27, (2010), doi: 10.1016/j.eiar.2009.05.001.

21. F. Coenen, "Public Participation and Better Environmental Decisions: Introduction," in Public Participation and Better Environmental Decisions, no. 1, Enschede: Springer, (2009), pp. 1-21.

22. R. Beitsch, "Environmental Review of Major Projects, ” (2020). https://thehill.com/policy/energyenvironment/501258-trump-signs-orderremoving-environmental-review-for-majorprojects (accessed Nov. 01, 2020).

23. K. Swain and S. Hausler, "Australia: The environmental impacts of COVID-19 recovery," (2020).

https://www.mondaq.com/australia/environme nt/951028/the-environmental-impacts-ofcovid-19-recovery (accessed Nov. 01, 2020).

24. UNECE, "Executive Secretary," (2020). https://www.unece.org/info/media/executivesecretary-blog/2020/environmentaldemocracy-in-times-of-covid-19/doc.html (accessed Nov. 01, 2020).

25. N. Hartley and C. Wood, "Public participation in environmental impact assessment - Implementing the Aarhus Convention, " Environ. Impact Assess. Rev., vol. 25, no. 4, pp. 319-340, (2005), doi: 10.1016/j.eiar.2004.12.002

26. gov.uk., "Consultation and pre-decision matters, " (2020).

https://www.gov.uk/guidance/consultationand-pre-decision-matters\#eia (accessed Nov. 01, 2020). 
27. J. L. Moorman and Z. Ge, "Promoting and Strengthening Public Participation in China , $s$ Environmental Impact Linked references are available on JSTOR for this article : A SSESSMENT P ROCESS : C OMPARING," vol. 8, no. 2, pp. 281-335, (2007).

28. Statistics Indonesia, "Proportion of Individuals Who Use the Internet by Province (Percent), 2017-2019," (2020).

https://www.bps.go.id/indicator/27/1225/1/pro porsi-individu-yang-menggunakan-internetmenurut-provinsi.html (accessed Nov. 19, 2020).

29. M. Roser, H. Ritchie, and E. Ortiz-Ospina, "Internet," (2019).

https://ourworldindata.org/internet (accessed Nov. 01, 2020). 